\title{
Participatory flood modelling for negotiation and planning in urban informal settlements
}

Joe Mulligan CEng, MICE, ACGI

Associate Director, Kounkuey Design Initiative, Stockholm, Sweden; Industrial PhD student, KTH Royal Institute of Technology, Stockholm, Sweden (corresponding author: joe@kounkuey.org; josephmu@kth.se) (Orcid:0000-0002-8614-3787)

\section{Vera Bukachi BEng, MPhil}

Research Director, Kounkuey Design Initiative, Nairobi, Kenya;

PhD candidate, Centre for Urban Sustainability and Resilience, University College London, London, UK

\section{Rodoula Gregoriou MEng, CEng, MICE}

Senior Engineer, Water, BuroHappold Engineering, Bath, UK

Nilani Venn MSci, MSc, C.WEM, CEnv, MCIWEM

Senior Engineer, Water, BuroHappold Engineering, Bath, UK
Duncan Ker-Reid MEng, CEng, MICE, ACGI

Associate Director, Water, BuroHappold Engineering, Bath, UK

Alan Travers BSC, CEng, MICE, MCIWEM

Partner, BuroHappold Engineering, Bath, UK

Juma Benard BSc, MSC

PhD candidate, Department of Civil Engineering, Technical University of Kenya, Nairobi, Kenya

Luke O. Olang BSc, MSc, PGDip, PhD

Senior Lecturer, Department of Biosystems and Environmental Engineering, Technical University of Kenya, Nairobi, Kenya; Humboldt Senior Researcher, Chair of Hydrology and River Basin Management, Technical University of Munich, Munich, Germany

Participatory modelling in water resource management - involving diverse actors in what is traditionally a purely analytical process - is thought to broaden stakeholder engagement and improve outcomes. Further research and case studies are required to explore the practicalities of integrating meaningful participation within modelling processes in the water sector. Participatory modelling may be of particular interest within the context of urban informal areas, where the confluence of climate change, urbanisation and contested land requires new methods for engagement and planning. This paper develops new case-based knowledge to inform the application of participatory modelling and planning for informal urban areas. A flood-modelling project in the large informal neighbourhood of Kibera in central Nairobi, Kenya, is analysed using a newly established framework for the classification of participatory modelling approaches developed by Basco-Carrera et al. in 2017. Conclusions suggest that the further upstream more diverse stakeholders can be involved, the better the chance of co-producing new knowledge and of creating implementable plans and policies. At the same time, delivering 'co-design' of modelling processes in areas of limited co-operation requires a strong vision for participation, a tolerance for contention, a willingness to learn between actors and a budget to support additional time inputs.

\section{Introduction: integrated water resources management, participation and computer modelling}

Integrated water resources management (IWRM) is a demandoriented approach, based on multidisciplinary activities, that has paved the way for increased and broadened stakeholder participation in planning and decision-making processes across the water sector (Agarwal et al., 2000; Mersha et al., 2018; Tortajada, 2014). The UN Sustainable Development Goals (SDGs), in particular SDG6, highlight the implementation of IWRM at all levels to ensure access to water and sanitation for all (Basco-Carrera et al., 2018). Participation in water management processes is seen to lead to increased transparency, democracy and empowerment of stakeholders (Hare et al., 2003; Rees, 1998). Local knowledge and expertise are seen as valuable tools for understanding local contexts and creating alternative and often more sustainable policy strategies (Borchardt et al., 2016; Warner, 2007). Broadened stakeholder participation in water management is also thought to lead to collaborative learning between stakeholders (Ouma et al., 2017; Voinov and Bousquet, 2010).

In recent years, computer-based models have become central to IWRM approaches (Olang and Furst, 2011). Although models present a simplification of complex systems, they can be considered as a useful tool for enhancing understanding of the behaviour of water systems (Jonsson et al., 2007). Models in IWRM are thought to account better for uncertainties, enhance the scientific basis for informed decision-making and support stakeholder dialogues (Haasnoot et al., 2014; Loucks et al., 2005).

Consequently, participatory modelling approaches have emerged in the water sector. Voinov and Gaddis (2008: p. 197) describe participatory modelling as 'the process of incorporating stakeholders - often the public - and decision makers into an otherwise purely analytic modelling process'. Stated benefits of participatory modelling in water management include the creation of a forum for broader participation, the capture of tacit and situated knowledge and the identification of a wider range of responses beyond the physical (Figueiredo and Perkins, 2013; Langsdale et al., 2013). Further scientific research is required to explore the use of computer-based models within participatory planning and decision-making processes in the water sector (Basco-Carrera et al., 2017; Kotir et al., 2017). Participatory methods are of particular interest within the context of urban informal areas, where the intersections of climate change, urbanisation and contested land call for new engagement and planning approaches. 
Section 2 provides further background on the key concepts, related literature and gaps in research and practice on $(a)$ the application of participatory modelling in the context of flood risk management (FRM); (b) the specific challenges and opportunities around participatory modelling in urban informal areas in rapidly urbanising cities; and $(c)$ the policy and practice context in the city and settlement where the case in this paper is based.

\section{Background: flooding and participatory flood modelling}

\subsection{FRM and participatory flood modelling}

Floods are the most frequent of all natural disasters (Jha et al., 2012; Salami et al., 2017). FRM comprises the holistic and continuous societal analysis, assessment and reduction of flood risk. As exposure and damages have increased, there has been a shift from traditional physical flood protection in FRM towards integrated flood management (IFM) (Kubal et al., 2009; Morrison et al., 2018; O'Neill, 2018). IFM values are reflected in the guiding principles of the 2015-2030 Sendai Framework for Disaster Risk Reduction, which emphasises the empowerment of local authorities and communities through decision-making responsibility and inclusiveness (Aitsi-Selmi et al., 2015).

Computer modelling is a powerful tool in FRM and IFM for characterising flood hazards (the type, depth, velocity and extent of flooding), flood risks (potential impacts) and as a decisionsupport system (DSS) for developing appropriate solutions (Jha et al., 2012). Participatory flood modelling is seen as having particular importance for including and applying the tacit and situated knowledge of local stakeholders and identifying 'soft' social and behavioural solutions in addition to 'hard' physical and engineered ones (Henriksen et al. 2018; Maskrey et al., 2016; Smith et al. 2017).

However, more evidence on the practicalities of participatory flood-modelling processes is required. In the European context, Haughton et al. (2015) suggest that more evidence is needed to prove the notion that stakeholder 'expertise' is actually of value in FRM. Maskrey et al. (2016) describe how despite 'legislative enthusiasm' for participation in environmental management in the UK and EU context, practical guidance on how to move beyond 'consultation' to make FRM, and flood modelling in particular, more participatory is sparse. Particular challenges highlighted include how to identify and engage appropriate stakeholder groups, the timing of participation (which stages of modelling different stakeholders are involved in) and how to move participation beyond being a tool for driving 'acceptance' to being a means of redistributing expertise and developing emergent learning (Landström et al., 2011). In a review of a geographic information system (GIS) and a DSS for urban flood risk, FrickTrzebitzky (2018) suggests that the scientific methods currently used in urban flood risk reduction are often inadequate to produce an overall picture of risks and vulnerabilities. A summary of the suggested benefits and limitations of participatory modelling in water management from the literature is given in Table 1.

\subsection{Participatory flood modelling in urban informal areas} In cities in low-income countries, the poorest and most vulnerable face increased exposure to flood risk due to rapid urbanisation and climate change (Bischiniotis et al., 2018; Engel et al., 2017; Jha et al., 2012). While the scale of flooding in urban Africa is not as catastrophic as in some Asian cities, continuous small-scale flooding can cripple the capacity of many residents to improve their conditions and move beyond merely 'coping' with risk (Bhattacharya and Lamond, 2011).

IWRM approaches are increasingly recognised and included in legislation, although many countries face challenges moving from flood response to FRM (Douglas, 2017; Mohamed, 2018). There is an urgent need for the application of IFM in urban contexts in many cities (Jha et al., 2012), including Kenya, where this study is set (Douglas, 2017; Ngobi and Mulligan, 2017). Flooding disproportionately affects residents of urban informal areas, who also face a participation gap due to the often-contested nature of land (Jha et al., 2012; Parikh et al., 2012). Tools for supporting

Table 1. A summary of suggested benefits and limitations of participatory modelling in water management from the literature

\begin{tabular}{|c|c|c|}
\hline & Potential benefits & Potential challenges \\
\hline \multirow[t]{2}{*}{ Process legitimacy } & Building trust, ownership and consensus & Used to legitimise top-down exercises \\
\hline & Legitimacy and support for decisions & Biases of those involved come to fore \\
\hline \multirow[t]{3}{*}{$\begin{array}{l}\text { Local knowledge } \\
\text { and collaborative } \\
\text { learning }\end{array}$} & Engages tacit and situated knowledge (Maskrey et al., 2016) & $\begin{array}{l}\text { Limits to the value of local } \\
\text { knowledge/romanticisation of participation as a } \\
\text { panacea (Haughton et al., 2015) }\end{array}$ \\
\hline & $\begin{array}{l}\text { Broadens menu of flood response options (social and behavioural } \\
\text { as well physical and engineered interventions) (Maskrey et al., } \\
\text { 2016) }\end{array}$ & $\begin{array}{l}\text { Conceptual and numerical simplification required } \\
\text { (Maskrey et al., 2016) }\end{array}$ \\
\hline & $\begin{array}{l}\text { Co-production of new knowledge; social and shared learning } \\
\text { (Evers et al., 2012; Hare, 2011; Voinov and Bousquet, 2010) }\end{array}$ & $\begin{array}{l}\text { Focus on producing agreement and better solutions } \\
\text { rather than new knowledge (Landström, 2011) }\end{array}$ \\
\hline \multirow[t]{2}{*}{ Negotiation } & $\begin{array}{l}\text { Opens channels of communication/fosters consensus among } \\
\text { competing organisations (Hare, 2011; Loucks et al., 2005) }\end{array}$ & $\begin{array}{l}\text { Risk reproduction of social relations that create risk } \\
\text { and vulnerability (Frick-Trzebitzky, 2018) }\end{array}$ \\
\hline & & $\begin{array}{l}\text { Larger planning processes cannot incorporate all } \\
\text { stakeholders (Maskrey et al., 2016) }\end{array}$ \\
\hline Value for money & Leads to more sustainable solutions in the long term & Costly and time consuming \\
\hline
\end{tabular}


negotiation between different stakeholders in such urban areas are hence of particular importance. Taylor (2015) shows how participatory governance approaches have opened dialogue with informal riverbank settlers to reduce flood risk in Indonesian cities.

In recognising the scale and growth of these challenges, a number of projects and programmes have sought to apply flood hazard and risk modelling specifically to urban informal areas (e.g. see the paper of De Risi et al. (2013) on Dar es Salaam, Tanzania, and that of Venkateshwarlu and Vijayabhole (2018) on Hyderabad, India). However, these examples do not explicitly incorporate participatory elements. In many cities, efforts to involve the worst affected stakeholders in data collection and mapping to support IFM are increasing (Jha et al., 2012). In Dar es Salaam for example, the ongoing Ramani Huria project is training students and local community members to create highly accurate maps of the most flood-prone areas of the city, covering both formal and informal areas (Ramani Huria, 2018). These examples do not necessarily involve diverse stakeholders in the model definition stages.

\subsection{Participatory processes in the water sector in Kenya} Within the past decade, the water sector in Kenya has been devolved from the national to the county government level (ROK, 2010, 2016). The Kenya Flood Mitigation Strategy is built on the concept of IFM (Mowi, 2009), and public participation in making key decisions around water, as well as other resources, is enshrined in the Constitution of Kenya (ROK, 2010). There has been some success in integrated and proactive IFM projects in rural areas, such as the Western Kenya Community Driven Development and Flood Mitigation Project in Budalangi (Senaratna et al., 2014; World Bank, 2007). More broadly, however, Van Oel et al. (2014) point to a lack of critical knowledge in IWRM, and Ondieki (2014) states that the principles of IWRM are yet to be adopted fully in Kenya.

In the urban context, there are very limited examples of the proactive use of IFM or related participatory processes (Douglas et al., 2008; Olang et al., 2012). This is manifested most starkly in the 'participation gap' between local authorities and residents of informal areas in Nairobi in particular. With respect to disaster risk management (DRM), Leck et al. (2018) point to a lack of clarity in roles and responsibilities in Nairobi County within the devolved governance structure. In some instances, government interventions have pursued forced evictions, which do not adhere to the most basic constitutional requirements for consultation or resettlement and cause mistrust of government and resistance from residents (Douglas et al., 2008; Makau, 2018). Karisa (2010) highlights the need for spatial and participatory tools to aid planning and negotiation within the many informal areas adjacent to Nairobi's major river systems, while Munene (2018) argues that the new constitution is not enough by itself to guarantee civil society involvement in planning with respect to climate and risk science, particularly in informal areas of the city.

\subsection{Flood modelling and participation in Kibera}

Kibera is located adjacent to the Ngong-Motoine River, one of three major river systems in the Nairobi River basin, with an upstream catchment of 4500 ha. Over 22000 Kibera residents live within $30 \mathrm{~m}$ of the river (KDI, 2018). Flood damages were collated by Map Kibera (2010). Fifty per cent of respondents (from a 963 household panel survey in high-exposure areas of Kibera) reported that their houses flooded in the 2015 March-April-May 'long rains' (Mulligan et al., 2017). While flooding is one specific climate-related risk in Kibera, it is also tied to a much broader set of issues: poverty, public health, livelihoods, social contract and urban fragility (Mitra et al., 2017).

Ongoing projects such as 'Towards Forecast Based Preparedness' (ForPAC) plan to enhance the existing Kenya Meteorological Department's probabilistic extreme rainfall and flood risk forecast information for Nairobi (ForPAC, 2018), including flood modelling in Kibera in 2018 and 2019. The UK Aid-funded Developing Anticipatory Risk Awareness \& Joint Action (Daraja) project aims to co-produce weather and climate information services, which are particularly relevant to poor urban communities in Tanzania (Dar es Salaam) and Kenya (Nairobi), including Kibera (Daraja, 2019). In 2019, the Swedish International Development Cooperation Agency (Sida)-funded 'Community-responsive Adaptation' project with the Technical University of Kenya aims to produce a two-dimensional flood model for the Kibera settlement to support local adaptation projects by residents and local authorities (Lucsus, 2019). To the authors' knowledge, no explicitly 'participatory' flood modelling had been produced for the Kibera settlement, or other informal areas of Nairobi, prior to the case study analysed in this paper.

\section{Research objective}

The objective of the research is to develop new case-based knowledge to inform the application of participatory flood modelling and participatory planning for low-income and informal urban areas. To achieve this, the paper analyses the case of a project initiated in 2015 that engaged residents and other stakeholders in the modelling of fluvial flood hazard in the lowincome and informal Kibera neighbourhood of Nairobi.

The case is analysed through the application of a newly established framework for categorising participatory modelling, developed by Basco-Carrera et al. (2017). Building on the Basco-Carrera et al. model, the paper includes detailed analysis of participation levels of the various stakeholder groups at different stages of the modelling process. The paper contributes to development of theory by also considering the utility of the Basco-Carrera framework through application on a real-world case.

To the authors' knowledge, there have been limited published results on flood-modelling processes in low-income and informal urban developments that are explicitly participatory in approach. As such, the results in the paper shed light on the benefits, drawbacks, potential and practicalities of achieving participatory modelling in an under-addressed and critical context in global development. 


\section{Methods: applying the Basco-Carrera framework for case analysis}

\subsection{Introduction to the reference framework for case} analysis

The case study discussed in this paper is analysed using a recently developed framework for the classification, identification and selection of participatory modelling approaches from BascoCarrera et al. (2017).

The Basco-Carrera framework builds on foundational concepts in planning literature including the Arnstein (1969) 'ladder of participation'. Mostert (2003) adapted the classic Arnstein ladder to create a typology of participation levels specifically for planning and management of water resources. The water-specific ladder includes one level of non-participation (ignorance), three levels of low participation (awareness, information and consultation) and three levels of high participation (discussion, co-design and co-decision-making).

Basco-Carrera et al. (2017) also emphasise the importance of negotiation to assist stakeholders' transition from dispute to cooperation in water resource management as a second key dimension of participation. The horizontal co-operation continuum, developed by Sadoff and Grey (2005) for negotiating complex political water resource disputes, differentiates four principal types of co-operation: unilateral action, coordination, collaboration and joint action. Taken together, these two dimensions (the ladder of participation and the co-operation continuum) are used as the $x$ and $y$ axes in the BascoCarrera et al. (2017) classification of participatory and collaborative modelling (see Figure 1).

Collaborative modelling is therefore distinguished from participatory modelling as a more intensive form of modelling that includes key stakeholder involvement in model definition and construction, as well as other phases of model use. Participatory modelling occurs across a wider spectrum and can involve lower levels of participation of key stakeholders, including at the consultation and information rungs of the ladder. Further discussion of the classification is included in the paper by BascoCarrera et al. (2017).

The stages of modelling identified in the paper by Basco-Carrera et al. (2017) with reference to the paper by Hare (2011) and as described in Figure 2 are

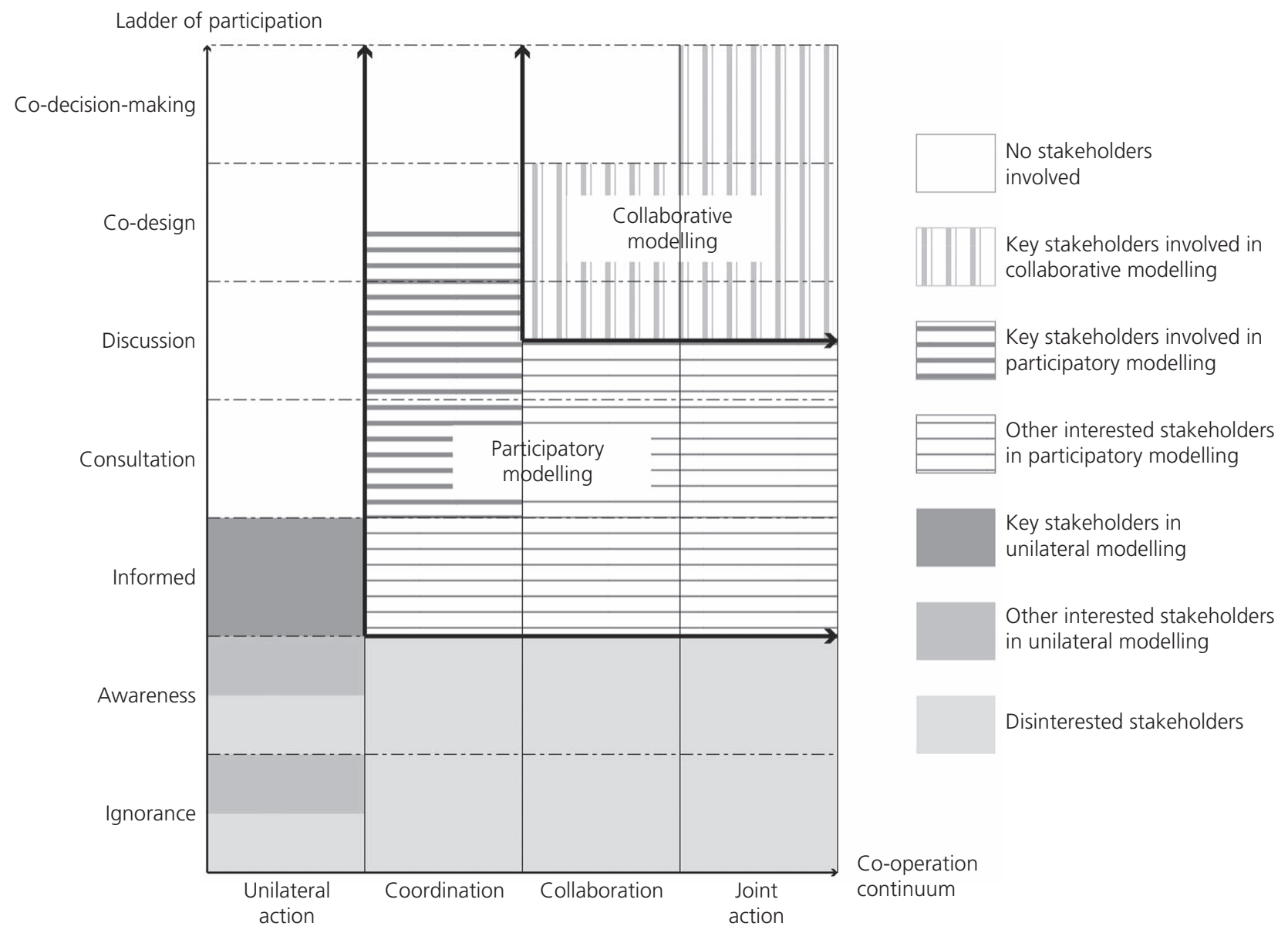

Figure 1. Classification of participatory and collaborative modelling from Basco-Carrera et al. (2017) 


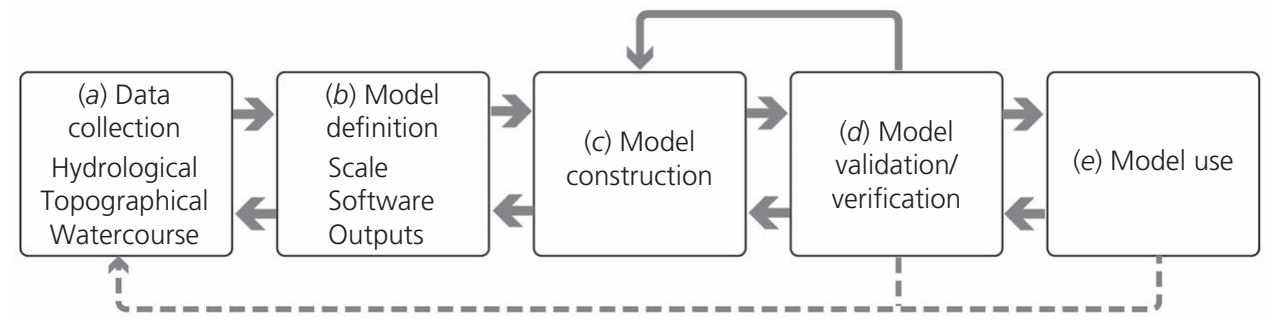

Figure 2. The stages of modelling for consideration of the timing of participation, adapted from Basco-Carrera et al. (2017)

(a) data collection

(b) model definition

(c) model construction

(d) model validation/verification

(e) model use.

Basco-Carrera et al. (2017) also put forward four generalised participatory modelling forms depending on this timing of involvement: front- and back-end, co-construction, front-end or backend (after the publications by Bots and van Daalen (2008) and Hare (2011)). Hare (2011) and Basco-Carrera et al. (2017) are clear that the classification and extent of participation and/or collaboration can be different at each stage of the modelling process.

The Basco-Carrera framework was subsequently applied in the realworld context of a groundwater-modelling process in the Netherlands in the original paper (Basco-Carrera et al., 2017) and in river basin management in Turkey (Basco-Carrera et al., 2018). The framework is used to categorise the cases in each paper as either a participatory or a collaborative modelling approach. In their 2018 paper, Basco-Carrera et al. (2018) used the framework to analyse and adapt an existing participatory modelling approach.

While there are other established frameworks for classifying different DSSs in water resources management (e.g. Loucks et al., 2005) and participatory modelling (Hare, 2011), the BascoCarrera et al. (2017) framework is the only one to classify modelling processes according to gradated scales of participation and co-operation, building on these earlier classifications.

\subsection{Applying the framework to the Kibera case}

The main tool put forward by Basco-Carrera et al. (2017) is a generic framework, in table format, that combines the definitions and typologies of participatory and collaborative modelling synthesised in the paper. The framework comprises 20 parameters categorised into six main factors: context and application, specific use, information handling, stakeholder involvement structure, modelling and organising team and means. The framework is intended to generalise case-specific participatory and collaborative modelling approaches, define their key characteristics and support categorisation (Basco-Carrera et al., 2017). The framework is applied to the Kibera case study in Table 2, and the results are discussed in Section 6.
The analysis in this paper applies the conceptual framework described in Figure 1 to the five stages of the modelling process described in Section 4.1 for each of the major stakeholder groups involved. Hence, stakeholder participation in the Kibera flood model is assessed in detail in the temporal dimension, as well as against the two interrelated axes of participation and collaboration. The results are discussed in Section 6.

\subsection{Data and sources}

Key references for carrying out the case analysis include the final project report on the case (KDI, 2017), an institutional mapping of FRM produced for the original project (Ngobi and Mulligan, 2017) and a write-up of the scoping and technical aspects of the modelling process by the modelling team (KDI, 2018). Other sources drawn on include discussions with key project stakeholders, project documentation from the delivery of the hydraulic model and write-ups from workshops related to the verification and application of the model.

\section{Case study: the Kibera flood model}

\subsection{Kibera flood model introduction and initial scope} In 2015, a 2-year 'action-research' programme entitled 'Building Urban Flood Resilience: Integrating Community Perspectives' was undertaken by the non-profit organisation Kounkuey Design Initiative (KDI). One of the principal activities was the development of a hydraulic flood model. The two intended outputs of the modelling process were (KDI, 2015)

- to produce flood depth and extent maps at a range of scales to support stakeholder consultations, overlay of community data and major and minor infrastructure planning (in a context where this had not been done before)

- to develop an open-source and free-to-use flood model to maximise the potential for adoption of the approach by institutional partners on the project (and other future potential users).

Overall, the project had the stated aim of bringing local (resident) knowledge into a technical modelling and subsequent design/ planning process, as well as engaging institutional actors responsible for FRM and DRM (KDI, 2015). Further supporting detail on the scoping of the project and modelling process can be found in the technical report (KDI, 2018). 


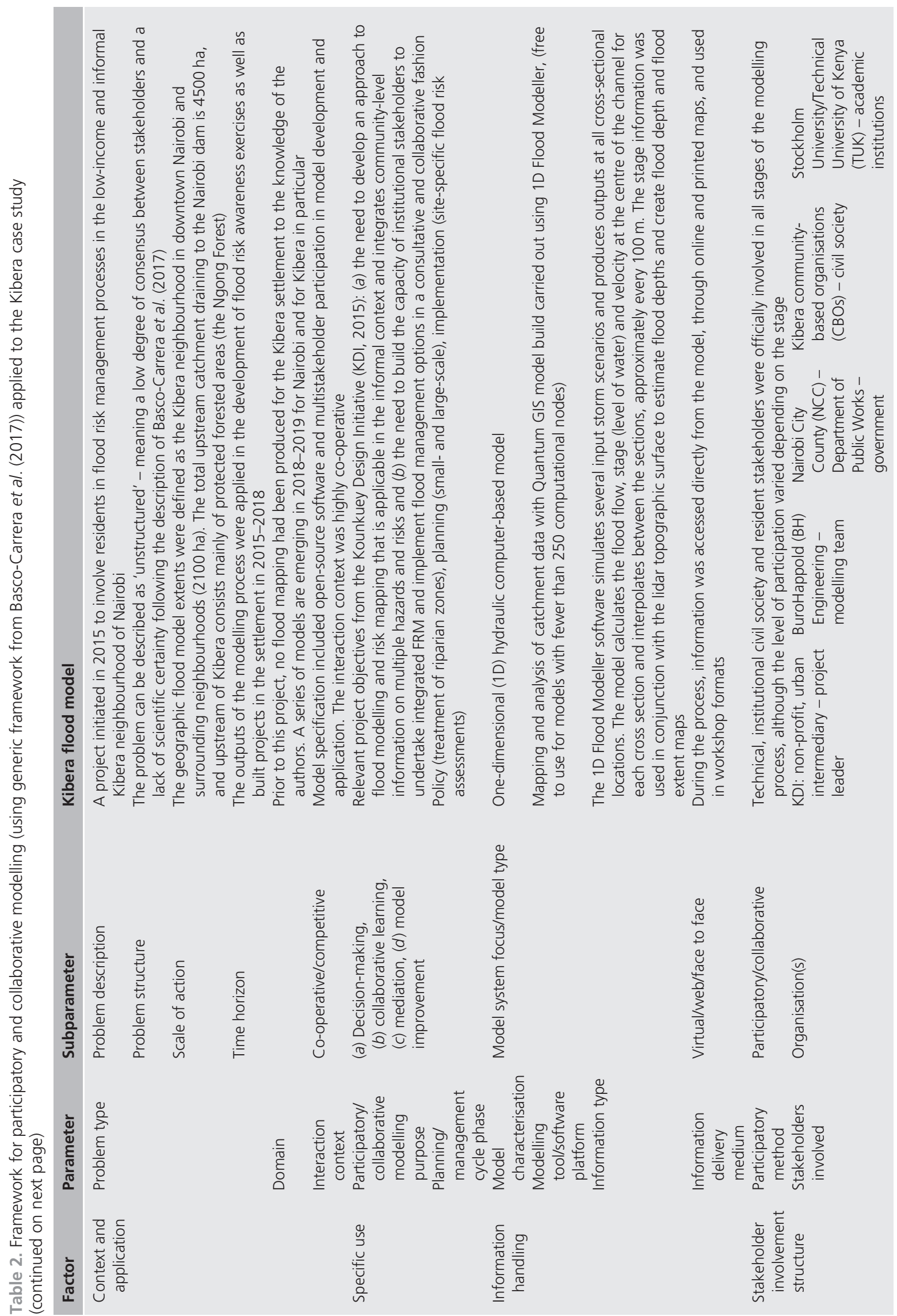




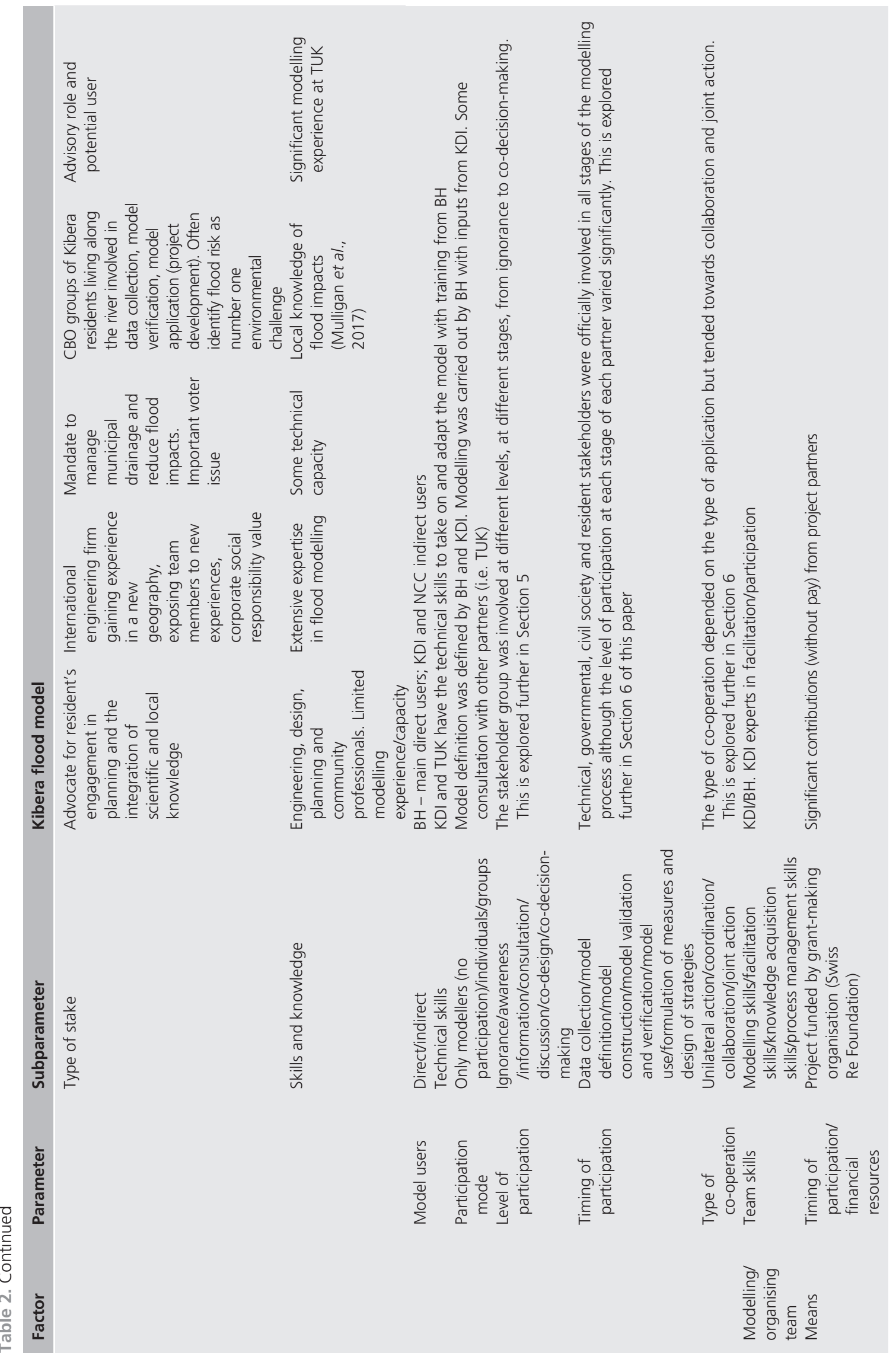




\subsection{Stakeholders in the Kibera flood model}

A list and descriptions of the stakeholders that were involved in the process at the various stages are given in Table 3 . Stakeholders are grouped according to five overarching categories: project coordinator (PC), modelling team (MT), public representatives (PR), government institutions (GI) and academic institutions (AI). These groupings and abbreviations are used for subsequent discussion and tracking of participation at the different stages of the process. These stakeholder groupings are mapped in Figure 3 using the quadrants of 'context users', 'subjects', 'key players' and 'crowd' (adapted from the publications by Eden and Ackermann (1998) and Maskrey et al. (2016)).

Table 3. A list and description of the stakeholders involved in the Kibera case study modelling process

\begin{tabular}{|c|c|c|c|}
\hline Organisation/group & Description & Participants & Macrogrouping \\
\hline $\begin{array}{l}\text { Kounkuey Design Initiative } \\
\text { (KDI) }\end{array}$ & Non-profit working in Kibera, project initiator & 18 & $\begin{array}{l}\text { Project } \\
\text { coordinator }\end{array}$ \\
\hline $\begin{array}{l}\text { Engineers without Borders } \\
\text { UK }\end{array}$ & Volunteer engineers with KDI & 9 & $(\mathrm{PC})$ \\
\hline \multirow[t]{3}{*}{ Kibera data collection team } & $\begin{array}{l}\text { Kibera residents tasked with collecting river-level data during the rainy season } \\
\text { to inform the model }\end{array}$ & 4 & \\
\hline & $\begin{array}{l}\text { Kibera residents tasked with collecting household data to compare to model } \\
\text { results }\end{array}$ & 7 & \\
\hline & $\begin{array}{l}\text { KDI field team of Kibera residents tasked with collecting data on river } \\
\text { structures }\end{array}$ & 2 & \\
\hline BuroHappold Engineering & UK-based modelling team & 4 & $\begin{array}{l}\text { Modelling team } \\
(\mathrm{MT})\end{array}$ \\
\hline $\begin{array}{l}\text { Andolo Bridge Community } \\
\text { Group }\end{array}$ & $\begin{array}{l}\text { Community-based organisation of Kibera residents involved in data collection, } \\
\text { model verification and model application (project development) }\end{array}$ & 20-30 & $\begin{array}{l}\text { Public } \\
\text { representatives }\end{array}$ \\
\hline Gifted Hands School & School stakeholders involved in model application (project development) & $20-30$ & (PR) \\
\hline $\begin{array}{l}\text { Institutional stakeholder } \\
\text { reference group }\end{array}$ & $\begin{array}{l}\text { Contributed to the institutional framework for FRM in Nairobi through key } \\
\text { informant interviews and ongoing consultation during the process }\end{array}$ & 24 & \\
\hline Stockholm University & Advisor on project design and monitoring and evaluation & 1 & Academic \\
\hline Technical University of Kenya & IWRM centre. Post-project reviewer and partner & 2 & institutions (AI) \\
\hline
\end{tabular}

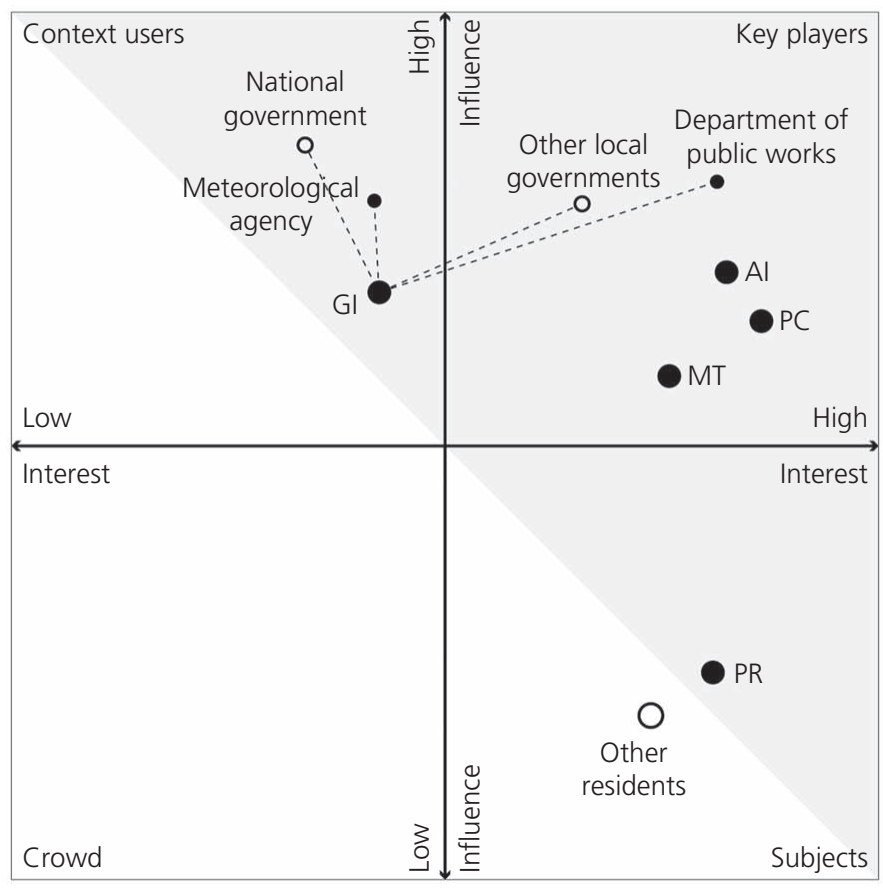

Engaged in Kibera model $\bigcirc$ Not engaged in Kibera model PC Project coordinator MT Modelling team PR Public representatives

Gl Government institutions

Al Academic institutions

High influence/ high interest

Figure 3. Mapping of stakeholders involved in the Kibera case study modelling process (following Eden and Ackermann (1998) and Maskrey et al. (2016)) 
The engagement of stakeholders was defined upfront largely by the project coordinator. However, new actors were also engaged through the process as knowledge and publicity around the project was widened. Stakeholder engagement, and the timing of engagement, is discussed in detail in the subsequent sections.

\subsection{Timing and extent of participation for different stakeholders in the Kibera flood model case}

The stages of model development in the case are described in detail in the following sections using the modelling stages defined by Basco-Carrera et al. (2017). Stakeholders are referred to by the groupings established in Table 3 and Figure 3.

\subsubsection{Data collection}

The initial scoping of the Kibera flood model defined the geographic scope and watercourses to be captured in the modelling process. Feedback from the project coordinator's field team identified anecdotal and physical evidence of significant flooding driven by local formal and informal infrastructures impeding flow during heavy rains. Subsequently, the project coordinator's field team (long-term Kibera residents) surveyed, classified, dimensioned, photographed and geo-tagged 64 key hydraulic structures and obstructions (bridges, culverts, pipelines and other major obstructions) along the main watercourses of Kibera using handheld Android devices and the Open Data Kit application. This enabled rapid and accurate representation of the structures within the Kibera flood model. The design of this survey was carried out by the project coordinator and modelling team with inputs from the project coordinator's field team.

\subsubsection{Model definition}

Model definition was carried out primarily by the project coordinator and the modelling team. The original project proposal stipulated that the model should be open source and free to use to maximise the potential for adoption of the approach by institutional partners on the project and other future potential users (KDI, 2015). Open-source or free software is identified as a key enabler of participatory and collaborative modelling approaches by Basco-Carrera et al. (2017).

Neither public representatives (community partners and residents) nor government institutions were aware of the modelling process at this stage. This contrasts with a number of participatory and collaborative approaches that actively involve diverse stakeholder groups in model definition and construction (e.g. Jonsson et al., 2007; Landström et al., 2011; Maskrey et al., 2016). Jonsson et al. (2007) warn that even though ambitions for real stakeholder influence in participatory modelling may be high and sincere, process initiators may unconsciously be carrying out a top-down approach. There is evidence of this in the earlier (and perhaps critical) stages of the Kibera case study, although the latter stages offered more examples of co-decision-making and joint action. For example, as the Kibera flood model was developed and different applications were piloted, other stakeholders, including government institutions, were involved in discussions that informed the evolution of the model (e.g. extending the model to cover certain tributaries of interest).

\subsubsection{Model construction}

Model construction was performed mainly by the modelling team, although the project coordinator was consulted at various stages for verification of assumptions and direction. Mapping and analysis of catchment data were carried out using the Quantum GIS software, and the model was built with the free-to-use 1D Flood Modeller platform. Other stakeholders were informed of the process but not consulted on the technical aspects of model construction. Community-based organisation partners and residents were informed and engaged in the collection of data that ran parallel to the modelling process. Further details on the hydraulic modelling process, assumptions and limitations can be found in Table 2 and in the technical report (KDI, 2018).

\subsubsection{Model validation/verification}

After completing the first iteration of the model in 2016, flood extent maps were prepared at a range of scales by the modelling team and the project coordinator to support model verification and calibration. In May 2016, the project coordinator ran workshops with residents in the Andolo neighbourhood of Kibera (a high-exposure area) where participants worked with aerial maps to identify local landmarks and the extents of historical events. These were overlain with the flood extents generated from the model to verify its accuracy/overlap with local information.

Figure 4 is an image taken from one of these workshops. Residents were exposed to flood maps for the first time and were able to connect their own experiences to the science-based outputs. These exercises built trust in the veracity of the modelling outputs, created an active discussion around flood risk and built confidence in the flood mitigation project that latterly took place in the same area (and which is described in Section 5.3.5). These could be considered examples of social learning where collective knowledge of complex systems and the

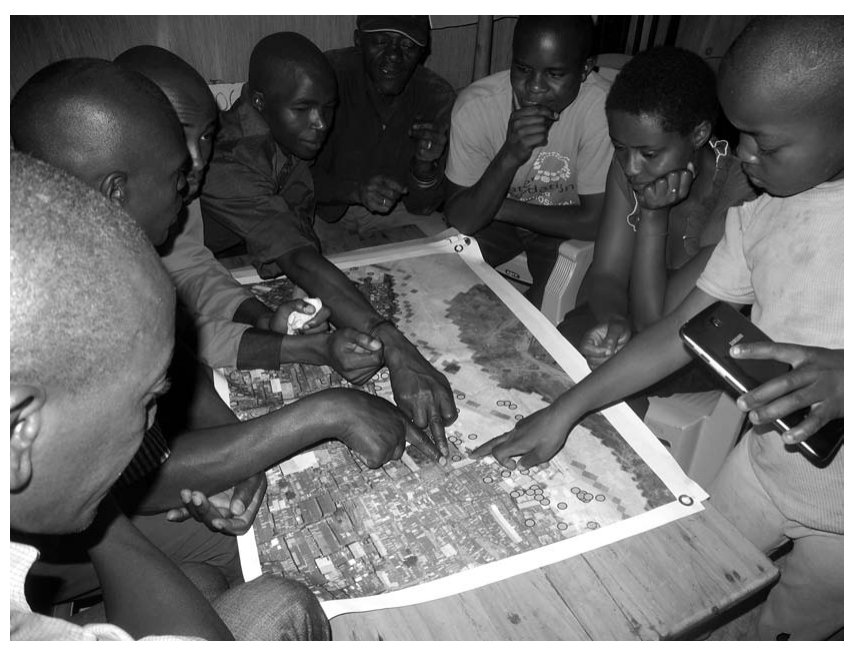

Figure 4. Workshops with residents in the Andolo neighbourhood of Kibera in May 2016 to identify local landmarks, the extents of historical events and the correspondence with modelled flood extents 
connections between physical and social dynamics are improved (Evers et al., 2012; Hare, 2011; Voinov and Bousquet, 2010).

\subsubsection{Model use}

\subsubsection{PLANNING}

Through the project coordinator's ongoing work with local authorities in Kibera, in particular the Nairobi County Council Department of Roads and Public Works, there have been multiple opportunities to apply the flood model in various planning exercises since 2016. These included the planning stages for a new road passing through Kibera and over the Ngong River and an assessment of the reasons behind the surcharging of a new public sewer line through Kibera. The County Executive for Public Works at the time noted that the collaboration 'has exposed county engineers to new technologies in drainage mapping and flood mitigation' (KDI, 2017: p. 77).

\subsubsection{ADVOCACY}

Overlay of flood extent data with household-level data produced by the project coordinator and modelling team is shown in Figure 5 and in the report by KDI (2018). These overlays identify linkages between flood exposure and socio-economic and demographic characteristics (e.g. the lower-rent areas correspond to high-exposure areas (see the report by KDI (2017))) and produce a broader understanding of risk. The map shown in Figure 5 and other similar maps and graphics were used in a number of forums, including Nairobi Design Week in 2015, multiple meetings with local authorities and a wider stakeholder convening in late 2016 (KDI, 2017). Although these efforts were initiated by the project coordinator, they also provided forums for public representatives and other residents to interact with government authorities.

\subsubsection{PROJECT DEVELOPMENT}

A flood protection and public space project in the high-exposure Andolo neighbourhood was developed by local partners in 2017 and 2018 and is currently under construction (see Figure 6). A 'site-specific flood risk assessment' was developed using flood maps shown in Figure 7 to identify how the proposed area for development could be affected by extreme flood events. Appropriate uses for the development site were decided through a series of 13 community workshops designed to mediate local

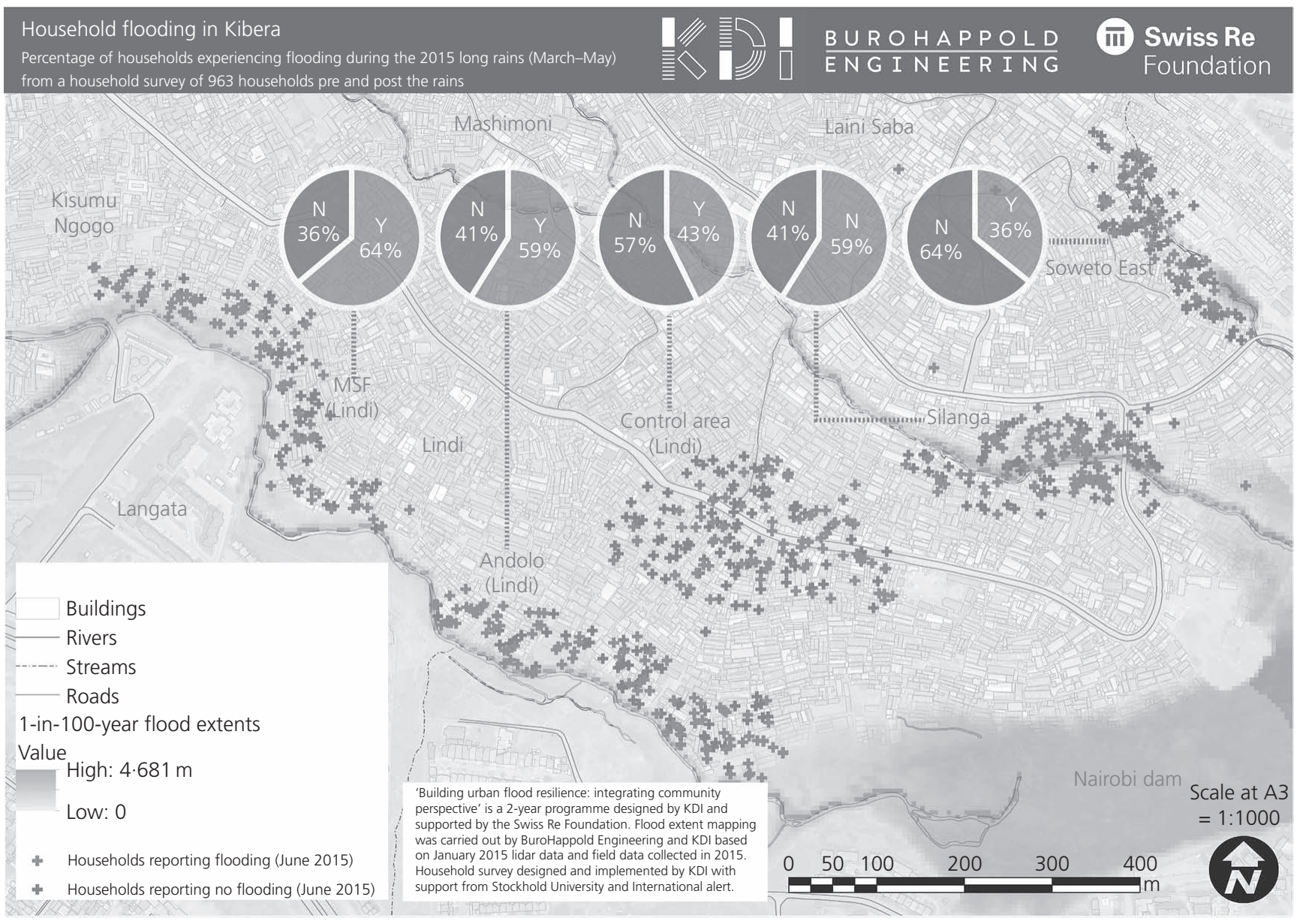

Figure 5. Overlay of flood extent data with household-level data (from KDI (2017)). MSF, medecins sans frontieres 


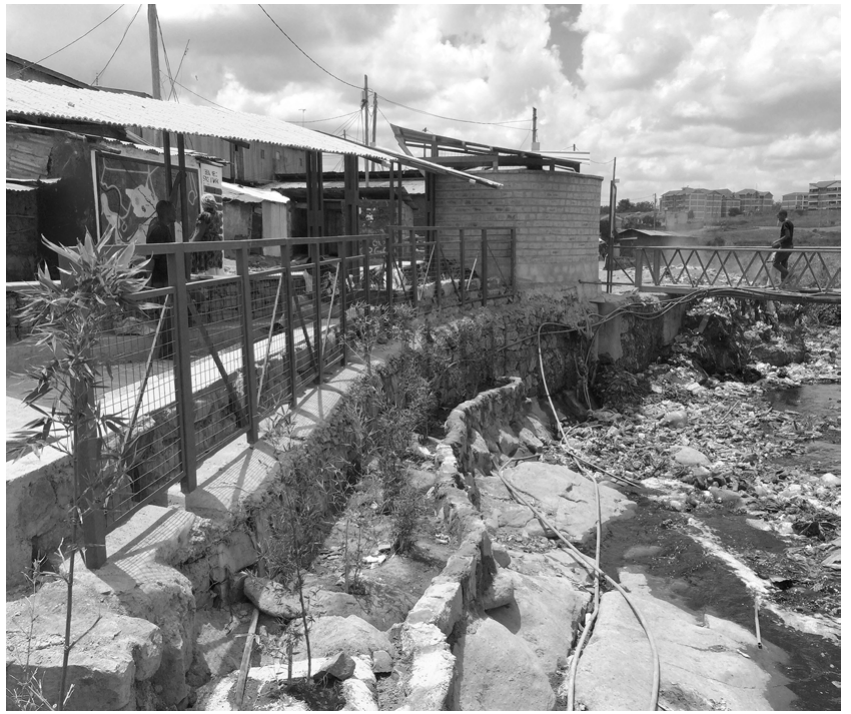

Figure 6. River remediation and flood protection project developed at Andolo with residents using flood model outputs (photograph: Jack Campbell Clause, KDI) experiences and the flood extent information. The community's prioritisation and selection of site features and programmes (flood protection, laundry pad, water point and play-space) were hence informed by both their situated understanding of risk and a science-based interpretation of potential flood hazard as represented by the model.

\subsubsection{ADAPTATION AND ADOPTION}

One key objective of the Kibera flood model build and development was to produce a tool that could be adopted and used by different local stakeholders. The 'live' nature of the model enables constant refinement and calibration to represent localities more accurately, as more data become available. This updating of the model was demonstrated in the Andolo project described earlier.

An essential element in meeting this objective was the preparation of a handover document to enable the use of the both the model and its outputs by a range of potential users. The user types envisaged by the project coordinator and modelling team are defined in Table 4 . The benefits and risks of this process are discussed further in Section 6.

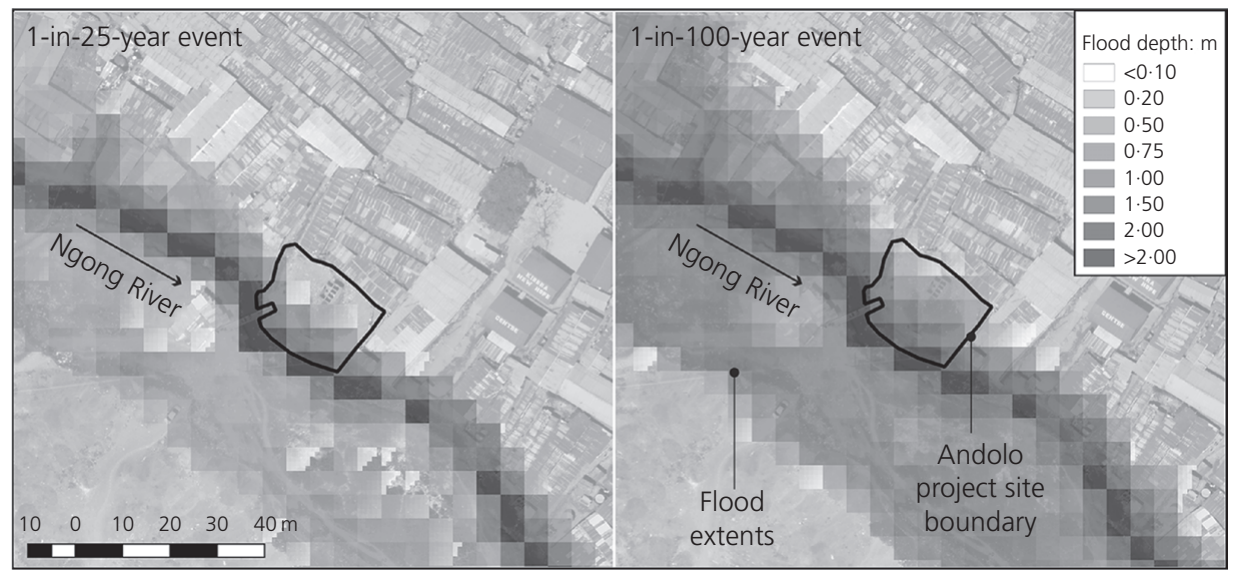

Figure 7. Flood maps used in site-specific flood risk assessment and workshops for the development of a flood protection and public space project in Andolo, Kibera in 2018 (source: KDI and BuroHappold Engineering)

Table 4. Range of potential users of both the Kibera open-source model and its outputs (from KDI (2018))

\begin{tabular}{|c|c|c|c|}
\hline User type & Description & Products used & Envisaged use \\
\hline $\begin{array}{l}\text { (a) Community } \\
\text { users }\end{array}$ & $\begin{array}{l}\text { Local communities, CBOs, non- } \\
\text { governmental organisations, } \\
\text { humanitarian groups }\end{array}$ & Flood extent maps & $\begin{array}{l}\text { Inform local community projects and develop } \\
\text { flood awareness and preparedness }\end{array}$ \\
\hline $\begin{array}{l}\text { (b) County } \\
\text { government }\end{array}$ & $\begin{array}{l}\text { Departments of Public Works, } \\
\text { Environment and Planning }\end{array}$ & $\begin{array}{l}\text { Flood extent maps + open-source } \\
\text { model (and instructions for model } \\
\text { modifications) }\end{array}$ & $\begin{array}{l}\text { Support implementation of a variety of scale } \\
\text { of projects at the local level }\end{array}$ \\
\hline $\begin{array}{l}\text { (c) National } \\
\text { government }\end{array}$ & $\begin{array}{l}\text { Institutional users with a good } \\
\text { understanding of model assumptions }\end{array}$ & $\begin{array}{l}\text { Open-source model (and instructions } \\
\text { for model modifications) }\end{array}$ & $\begin{array}{l}\text { Scaling out (and up) of the model through } \\
\text { policy development and adoption }\end{array}$ \\
\hline $\begin{array}{l}\text { (d) Research } \\
\text { community }\end{array}$ & Universities and research centres & $\begin{array}{l}\text { Open-source model (and instructions } \\
\text { for model modifications) }\end{array}$ & $\begin{array}{l}\text { Enhance and improve the capabilities of the } \\
\text { tool according to changing demands and } \\
\text { conditions }\end{array}$ \\
\hline
\end{tabular}




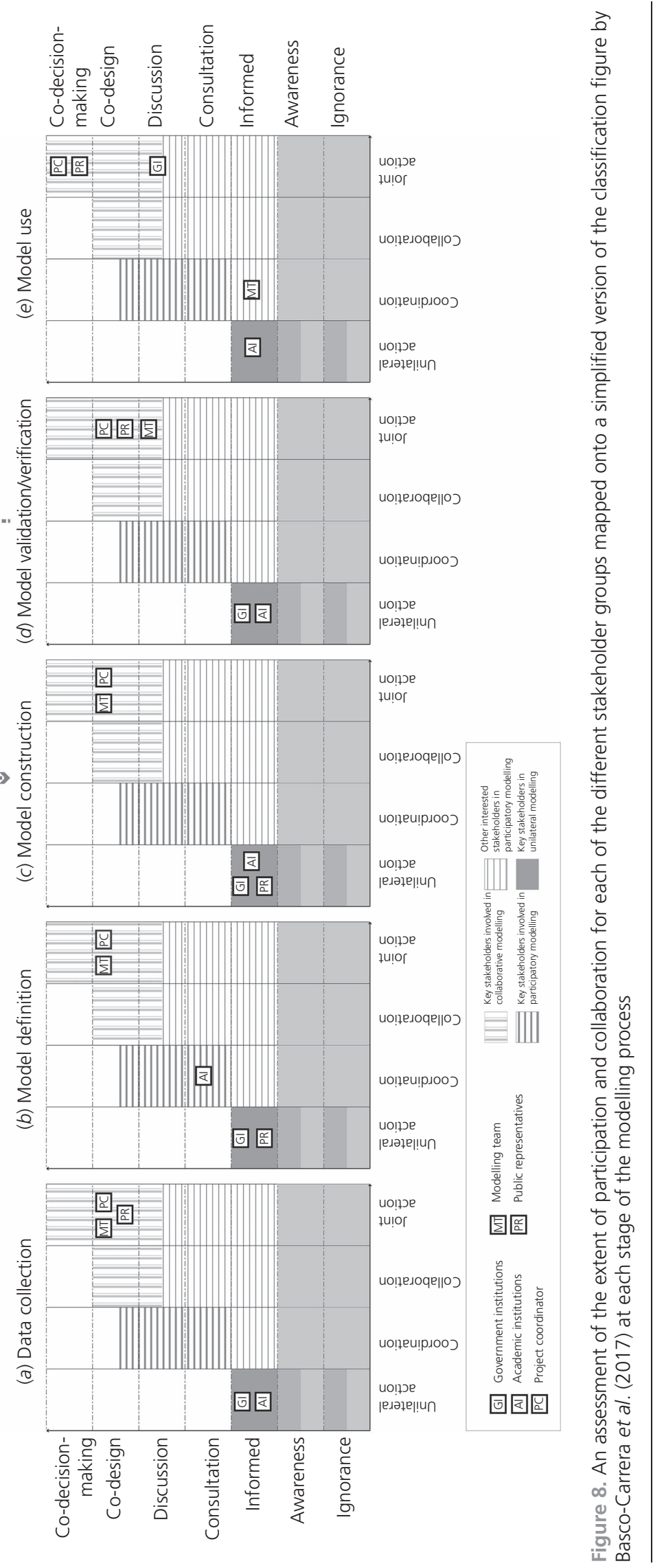




\section{Findings and discussion}

\subsection{Findings on the utility and potential applications of the Basco-Carrera framework}

Applying the Basco-Carrera framework to this case clearly demonstrates its stated aims of $(a)$ defining the generic characteristics and features (trade-offs) of existing participatory and collaborative modelling approaches and tools and $(b)$ generalising case-specific participatory and collaborative modelling approaches.

Table 2 describes the case study using the 'framework for participatory and collaborative modelling' by Basco-Carrera et al. (2017). In general, the table is useful for giving an overview of the context and participatory characteristics of the modelling process based on the synthesised definitions from an extensive review of literature on this subject. From applying the framework, it is immediately clear that the modelling process, in this case, is clearly participatory rather than collaborative. In the collaborative model, key stakeholders are involved in 'all stages of model development, including construction', whereas in the participatory version 'model construction is generally performed by the modelling team'.

The results in Figure 8 demonstrate visually the participation journey of the various stakeholder groups and highlight some critical features of the case. For example, the 'model definition' phase exhibited a low degree of public and government stakeholder influence over the model-definition process and a tendency towards 'expert knowledge dominance' on the part of the project coordinator and modelling team in these early stages. In later stages, the levels of participation of most stakeholders increased, in particular for the public representatives, who go from ignorance of the process in model definition to active involvement in data collection and co-design and decision-making in model use and application. Overall, the case can be described as being principally a 'back-end' mode of participatory modelling (after the publications by Bots and van Daalen (2008), Hare (2011) and Basco-Carrera et al. (2017)), although it does have components of 'front-end' with resident involvement in data collection.

The application of the framework in this visual and temporal manner shown in Figure 8 clearly illustrates these transitions and helps characterise the level of participation that the case could claim to have achieved. Although this process is not suggested as an application of the framework by Basco-Carrera et al. (2017), it is considered an additional and potentially illuminating application of the tools developed to date. This application could be a useful design tool in the scoping stages of future participatory modelling exercises to help plan and widen stakeholder involvement throughout the process.

\subsection{Implications for participatory flood modelling for low-income and informal urban areas}

\subsubsection{The role of residents and intermediary} organisations

Resident participation in data collection, verification and model use had very demonstrable benefits in model accuracy and process legitimacy. In-depth local knowledge was required to map and add local structures into the Kibera flood model, which was fundamental in revealing their significant impact on localised flooding - this would not have been captured from remote sensing data alone. This process also served to verify reported experiences and build confidence in the flood maps, as residents could very easily see the impact of those local structures. Figure 9 shows an example of this localised flooding driven by an undersized bridge structure in the Makina village of Kibera.

Overall, these elements of engagement built an understanding of the model's aims among residents, expanded the modelling team's understanding of the local physical drivers of flood risk particular to urban informal settlements and highlighted the challenges of undersized and/or non-designed infrastructure to local authorities. This could be considered an example of what Voinov and Bousquet (2010) call 'shared learning' (also referred to as colearning), whereby information and knowledge flow from the organising team - including researchers and modellers - to stakeholders, and vice versa.

The relatively high levels of resident engagement in the Kibera flood model case were facilitated by a technically literate local partner who could engage with the modelling team, as well as having access and legitimacy in the targeted communities. Local authorities would ideally be able to develop and apply similar types of tools internally or better scope services to engage local consultants or intermediary organisations to produce similar tools or assessments. This would ensure sustainability, ownership and control over the process and could align more directly with government-implemented development initiatives. In areas where this does not exist, a well-trusted intermediary or 'boundary' organisation may still be required to enable effective participation and close the participation gap between formal city processes and informal neighbourhoods. The partnership between engineers, civil society organisations, academics, local authorities and the public described in the Kibera flood model case could be encouraging and instructive for more integrated and responsive practices in Nairobi, as well as in other cities in Kenya and more widely.

\subsubsection{Potential of participatory modelling as a planning and negotiation tool in the context of contested land}

In the Kibera flood model case, flood hazard mapping proved to be an effective advocacy tool in enabling straightforward consideration of flood risk at a level of detail not previously available. Public and civil society involvement also led to better understanding and acceptance of proposed interventions at the local scale. At the same time, the case also demonstrated low levels of involvement of government institutions in the earlier stages of the project. This may reflect the relatively low level of engagement of government institutions in general and the relative strength of civil society organisations in this space. This reflects a key challenge highlighted in the literature - the need for improved 


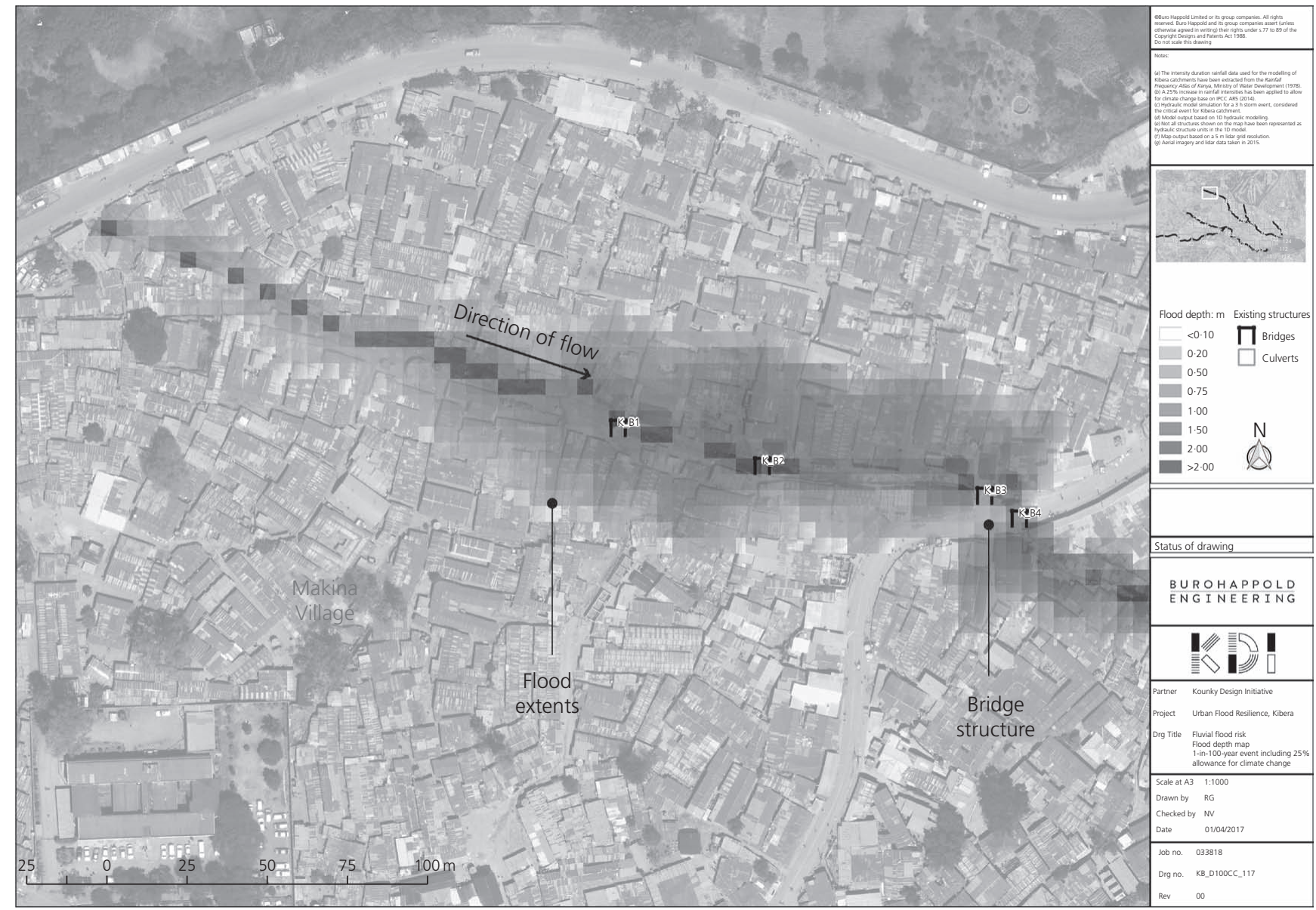

Figure 9. Model outputs for a 1-in-100-year flood extents demonstrating localised flooding driven by a bridge structure in the Makina village of Kibera (source: BuroHappold Engineering)

trust and co-operation between sectors of urban society (e.g. see the publications by Lwasa (2010) and Douglas (2017)).

The engagement of Nairobi City County in the latter stages when approvals and permits were sought for infrastructure development demonstrated the potential value of the modelling process as an entry point for macroplanning discussions on river rehabilitation and slum upgrading. Flood extent information was readily understood at the various governmental levels from both political and technical staff, suggesting that this is a good format for working with municipal partners. This can be seen as a potential segue to addressing the thornier issues of contested land. A critical sticking point raised by governmental stakeholders is the challenge of moving residents and structures from high-exposure areas (KDI, 2017). The existing blanket riparian-zone policy in Kenya has proved hard to enforce and expensive (Mwiti, 2014). Having a more nuanced understanding of flood extents and housing patterns would allow for more responsive and costeffective plans for rehabilitation and rehousing where necessary. Involving residents and civil society organisations in the front-end process of modelling floods, and the testing of subsequent policy and planning options, could build trust in the intentions of the government and develop alternative options for consideration. In the Nairobi context, however, this would require a step change in government approach at local and national levels, both in developing public policy vehicles for participatory IWRM and DRM approaches and in meaningfully engaging the communities most affected.

\subsubsection{Implications of open source for transferability and quality assurance}

By creating a hydraulic flood model that could be adopted by different stakeholders, the case study model was designed to be updated to meet the needs of the specific user, whether for local design initiatives or for larger infrastructure planning. The project coordinator and modelling team identified three main challenges envisaged with handing over the hydraulic model and its results (KDI, 2018).

- The adoption of the model by different parties could hinder effective maintenance and quality assurance, potentially making the outputs inaccurate in the future. 
- Input parameters and key assumptions must be clearly understood by users in order to build trust in the model and an understanding of its limitations in application.

- If inexperienced stakeholders use the model, they could inadvertently change fundamental parameters or have issues interpreting the results correctly.

At the time of writing, there is co-operation with two institutional partners in the application of the model. Some of the challenges and opportunities highlighted earlier will be brought to the surface through this process and would be worthy of further study and dissemination.

One particular constraint highlighted by the project coordinator (KDI, 2018), related to the cost of expanding the model to other areas, could be the cost of high-quality remote sensing data to enable detailed modelling. Further analysis is required to understand the difference in results provided by purchased against freely available satellite data to evaluate the additional value of the higher-resolution data used in this case.

\subsubsection{Value for money}

All groups (residents, technical experts and government representatives) in the Kibera case expressed a clear appreciation of the knowledge gained from their counterparts in the process. At the same time, the participatory approach described in the Kibera model required significant additional time costs associated with local data collection and workshops. The projects initiated through use of the model outputs would be possible without the participatory parts of the modelling process, but their success in terms of acceptance and longer-term sustainability may have been less guaranteed. Further research on the time and asset costs of different stages of modelling against quantifiable and perceived benefits would be valuable to inform future modelling and project processes as well as policy.

\subsubsection{Participation for whom and for what?}

This Kibera flood model case highlights the tricky transition from active involvement of stakeholders (in particular, residents) in decisions downstream to active engagement of wider sets of stakeholders in the framing and technical components of the process. It also raises a question of the role of non-technical stakeholders in the model definition and construction stages, particularly in urban informal areas where residents may face particular obstructions (lack of social contract, limited participatory processes in general, low exposure to mapping and related technical experiences).

Landström et al. (2011) suggest that in order for scientific modelling to contribute to the co-production of new knowledge claims about environmental processes, scientists need to reposition themselves with respect to their modelling practices. Participatory processes that harness the energy generated in public controversy and enable other groups to contribute to environmental knowledge are put forward as way to achieve this (Landström et al., 2011). Given the large amount of controversy around land tenure and riparian rehabilitation in the urban informal context, this may represent an interesting approach. A relatable concept from the perspective of residents comes from Sheela Patel, a founder of Slum Dwellers International, who stated the following in 2018 in Stockholm: 'When a woman in the slum feels like she can hold a professional to account, then we have progress'. Having these groups in the same room at certain points suggests that there is value in the types of interactions described by Patel. At the same time, the latent tensions between resident and government actors that may exist in the informal context require careful facilitation.

Ultimately, the upfront decisions about the degree of stakeholder involvement often come from influential decision makers (i.e. government and donors), but it may be influenced by others (i.e. technical team, civil society and influential intermediaries). If the goal is to co-produce new knowledge and create new policy options, the results from the Kibera model suggests that the further upstream more diverse stakeholders can be involved, the better. At the same time, this may require a strong vision for participation, an appetite for contention, a willingness to learn and a budget to the support additional time inputs that come with more engagement.

\section{Conclusions: to consultation and beyond}

With the predicted growth of many cities and climate change projections for increasing extreme rainfall events, the impacts of flooding in low-income and informal areas will continue to grow. The pressure on local authorities to recognise the rights, needs and specific vulnerabilities of residents of informal areas will also increase and will require improved technical and social tools and approaches. As the need for more participatory and grounded processes increases, the application of participatory flood modelling and the principles behind it could become extremely valuable.

The case of the Kibera flood model demonstrates that flood modelling can support the characterisation of the scale and spatial distribution of risk in urban informal areas. It also shows that participation in components of the modelling process can improve accuracy as well as increase acceptance and understanding of proposed solutions. In particular, the engagement of residents in data collection and model application showed real results in incorporating local knowledge and raising awareness of flood risk locally, as evidenced in the design and planning applications described in Section 4.

Although problem definition in the Kibera flood model case was informed by local residents' perspectives and ambitions for high levels of stakeholder influence (i.e. 'co-design and co-decisionmaking'), the conception of the process contained some 'top-down' characteristics (or 'middle-down', given that it was initiated by a boundary organisation). Engagement of local authorities did provide an entry point for discussing pressing flooding challenges in low-income areas where government activities and access may be limited. More generally, though, local authorities would ideally be able to initiate and develop 
similar types of modelling tools internally or better scope services to engage local consultants and intermediary organisations to produce similar tools or assessments. This would ensure ownership and control over the process and align more directly with larger government-implemented development initiatives.

The framework developed by Basco-Carrera is useful in its stated aims of supporting the classification and identification of participatory and collaborative modelling approaches. The emphasis on the levels of participation at different stages of the modelling process developed in this paper could also be useful in scoping future participatory modelling exercises, to help envision and plan for stakeholder involvement throughout the process. There is an implicit assumption that 'more participation' is a good thing, although as discussed here, there are careful considerations to be made about the timing and nature of participation. An understanding of the time, resources and competencies required to facilitate effective participation has to be factored in at the scoping stage.

\section{Acknowledgements}

The case study at the basis of this paper was part of a 2-year actionresearch study in 2015 and 2016 entitled 'Building Urban Flood Resilience: Integrating Community Perspectives', developed by the non-profit organisation Kounkuey Design Initiative (KDI) with support from BuroHappold Engineering, Stockholm University and Engineers without Borders UK and funded by the Swiss Re Foundation. Collaboration with the Technical University of Kenya was enabled under the Sida- and Swedish Research Council-funded 'Community-responsive Adaptation' research project in 2017-2019 with Stockholm University, KTH Royal Institute of Technology, Lund University and KDI.

\section{REFERENCES}

Agarwal A, delos Angeles MS, Bhatia R et al. (2000) Integrated Water Resources Management. Global Water Partnership, Stockholm, Sweden, Technical advisory committee, background paper No.4. Aitsi-Selmi A, Egawa S, Sasaki H, Wannous C and Murray V (2015) The Sendai Framework for Disaster Risk Reduction: renewing the global commitment to people's resilience, health, and well-being. International Journal of Disaster Risk Science 6(2): 164-176, https:// doi.org/10.1007/s13753-015-0050-9.

Arnstein SR (1969) A ladder of citizen participation. Journal of the American Institute of Planners 35(4): 216-224.

Basco-Carrera L, Warren A, van Beek E, Jonoski A and Giardino A (2017) Collaborative modelling or participatory modelling? A framework for water resources management. Environmental Modelling \& Software 91: 95-110, https://doi.org/10.1016/j.envsoft.2017.01.014.

Basco-Carrera E, Meijers HD, Sarısoy NO et al. (2018) An adapted companion modelling approach for enhancing multi-stakeholder cooperation in complex river basins. International Journal of Sustainable Development \& World Ecology 25(8): 747-764, https:// doi.org/10.1080/13504509.2018.1445668.

Bhattacharya-Mis N and Lamond J (2011) A review of urban flood risk situation in African growing economies. Proceedings of the International Symposium on Urban Flood Risk Management, Graz, Austria.

Bischiniotis K, van den Hurk B, Jongman B et al. (2018) The influence of antecedent conditions on flood risk in sub-Saharan Africa. Natural
Hazards and Earth System Sciences 18(1): 271-285, https://doi.org/10. 5194/nhess-18-271-2018.

Borchardt D, Bogardi Janos J and Ibisch RB (2016) Integrated Water Resources Management: Concept, Research and Implementation. Springer, Cham, Switzerland.

Bots PWG and van Daalen (2008) Participatory Model Construction and Model Use in Natural Resource Management: a Framework for Reflection 21(6): article 389, https://doi.org/10.1007/s11213-008-9108-6.

Daraja (Developing Anticipatory Risk Awareness \& Joint Action) (2019) https://beta.metoffice.gov.uk/about-us/what/working-with-otherorganisations/international/projects/wiser/daraja (accessed 03/04/2019).

De Risi R, Jalayer F, De Paola F et al. (2013) Flood risk assessment for informal settlements. Natural Hazards 69(1): 1003-1032, https://doi. org/10.1007/s11069-013-0749-0.

Douglas I (2017) Flooding in African cities, scales of causes, teleconnections, risks, vulnerability and impacts. International Journal of Disaster Risk Reduction 26: 34-42, https://doi.org/10.1016/j.ijdrr.2017.09.024.

Douglas I, Alam K, Maghenda M et al. (2008) Unjust waters: climate change, flooding and the urban poor in Africa. Environment and Urbanization 20(1): 187-205, https://doi.org/10.1177/0956247808089156.

Eden C and Ackermann F (1998) Making Strategy: the Journey of Strategic Management. Sage, London, UK.

Engel T, Fink AH, Knippertz P, Pante G and Bliefernicht J (2017) Extreme precipitation in the West African cities of Dakar and Ouagadougou: atmospheric dynamics and implications for flood risk assessments. Journal of Hydrometeorology 18(11): 2937-2957, https://doi.org/10. 1175/JHM-D-16-0218.1.

Evers M, Jonoski A, Maksimovic C et al. (2012) Collaborative modelling for active involvement of stakeholders in urban flood risk management. Natural Hazards Earth System Science 12(9): 2821-2842, https://doi.org/10.5194/nhess-12-2821-2012.

ForPac (Towards Forecast Based Preparedness) (2018) Nairobi Urban Flooding. ForPac, Sussex, UK. See https://www.forpac.org/about-us (accessed 22/12/2018)

Frick-Trzebitzky F (2018) GIS - What Can and What Can't It Say about Social Relations in Adaptation to Urban Flood Risk? UrbanArk, London, UK. See https://www.urbanark.org/sites/default/files/ resources/URBAN\%20ARK\%20Working\%20Paper\%20Frick-Trz.pdf (accessed 05/04/2019).

Haasnoot M, Van Deursen W, Guillaume JH et al. (2014) Fit for purpose? Building and evaluating a fast, integrated model for exploring water policy pathways. Environmental Modelling \& Software 60: 99-120.

Hare M (2011) Forms of participatory modelling and its potential for widespread adoption in the water sector. Environmental Science \& Policy 21(6): 386-402, https://doi.org/10.1002/eet.590.

Hare M, Letcher R and Jakeman A (2003) Participatory modelling in natural resource management: a comparison of four case studies. Integrated Assessment 4(2): 62-72, https://doi.org/10.1076/iaij.4.2.62.16706.

Haughton G, Bankoff G and Coulthard T (2015) In search of 'lost' knowledge and outsourced expertise in flood risk management. The Transactions of the Institute of British Geographers 40(3): 375-386, https://doi.org/10.1111/tran.12082.

Henriksen HJ, Roberts MJ, van der Keur P et al. (2018) Participatory early warning and monitoring systems: a Nordic framework for web-based flood risk management. International Journal of Disaster Risk Reduction 31: 1295-1306, https://doi.org/10.1016/j.ijdrr.2018.01.038. IPCC (Intergovernmental Panel on Climate Change) (2014) Contribution of working group II to the fifth assessment report of the intergovernmental panel on climate change. In Climate Change 2014: Impacts, Adaptation, and Vulnerability. Part B: Regional Aspects (Barros VR, Field CB, Dokken DJ et al. (eds)). Cambridge University Press, Cambridge, UK and New York, NY, USA.

Jha AK, Bloch R and Lamond J (2012) Cities and Flooding: a Guide to Integrated Urban Flood Risk Management for the 21st Century. World Bank, Washington, DC, USA. 
Jonsson A, Andersson L, Alkan-Olsson J and Arheimer B (2007) How participatory can participatory modelling be? A discussion of the degree of influence and stakeholder and expert perspectives in six dimensions of participatory modelling. Water Science and Technology 56(1): 207-214, https://doi.org/10.2166/wst.2007.453.

Karisa C (2010) A negotiated framework for rehabilitation of riparian zones in Nairobi City: the case of Mathare River Valley (Kenya). Proceedings of the ISOCARP Congress 2010: Sustainable CityDeveloping World, Nairobi, Kenya.

KDI (Kounkuey Design Initiative) (2015) Consultation and Data Collection Methodology for the Building Urban Flood Resilience in Kibera Project. KDI, Los Angeles, CA, USA. See http://www. kounkuey.org/150323\%20KDI\%20Urban\%20Flooding\% 20Consultation \%20and\%20Data\%20Collection \%20Methodology $\%$ 20REV01.pdf (accessed 03/09/2018).

KDI (2017) Building Urban Flood Resilience: Integrating Community Perspectives - Final Report. KDI, Los Angeles, CA, USA. See http:// www.kounkuey.org/Report_170414\%20Swiss\%20Re\%20Final\% 20NARRATIVE\%20Report\%20Screen.pdf (accessed 03/09/2018).

KDI (2018) Integrated Flood Risk Management in Slums - Applying $1 D$ Modelling in Kibera, Nairobi. KDI, Los Angeles, CA, USA. See http://www.kounkuey.org/Report_170403_Kibera_Flood_Model ICE_Paper_MainText_Submitted.pdf (accessed 03/09/2018).

Kotir JH, Brown G, Marshall N and Johnstone R (2017) Systemic feedback modelling for sustainable water resources management and agricultural development: an application of participatory modelling approach in the Volta River Basin. Environmental Modelling \& Software 88: 106-118, https://doi.org/10.1016/j.envsoft.2016.11.015.

Kubal C, Haase D, Meyer V et al. (2009) Integrated urban flood risk assessment - adapting a multicriteria approach to a city. Natural Hazards and Earth Systems Sciences 9(6): 1881-1895, https://doi.org/ 10.5194/nhess-9-1881-2009.

Landström C, Whatmore SJ, Lane SN et al. (2011) Coproducing flood risk knowledge: redistributing expertise in critical 'participatory modelling'. Environment and Planning A: Economy and Space 43(7): 1617-1633, https://doi.org/10.1068\%2Fa43482.

Langsdale SA, Beall E, Bourget E et al. (2013) Collaborative modeling for decision support in water resources: principles and best practices. JAWRA: Journal of the American Water Resources Association 49(3): 629-638, https://doi.org/10.1111/jawr.12065.

Leck H, Pelling M, Adelekan I et al. (2018) Towards risk-sensitive and transformative urban development in sub Saharan Africa. Sustainability 10(8): article 2645, https://doi.org/10.3390/su10082645.

Loucks P, Beek E, Stedinger J, Dijkman JPM and Villars MT (2005) Water Resources Systems Planning and Management: An Introduction to Methods, Models And Applications. UNESCO, Paris, France.

Lucsus (Lund University Centre for Sustainability Studies) (2019) Inclusive Resilience-Building to Floods in Informal Settlements, Lucsus, Lund University, Lund, Sweden. See https://www.lucsus.lu.se/research/ urban-governance/inclusive-resilience-building-to-floods-in-informalsettlements (accessed 03/05/2019).

Lwasa S (2010) Adapting urban areas in Africa to climate change: the case of Kampala. Current Opinion in Environmental Sustainability 2(3): 166-171, https://doi.org/10.1016/j.cosust.2010.06.009.

Makau J (2018) The protest, the representatives, and the petition: Kenya evictions diary. Muungano, 10 August. See https://www.muungano. net/browseblogs/2018/8/9/the-protest-the-representativesand-thepetition (accessed 03/09/2018).

Map Kibera (2010) Mapping Flood Damage in Kibera. Map Kibera, Nairobi, Kenya. See http://www.mapkibera.org/blog/2010/08/28/ mapping-flood-damage-in-kibera/ (accessed 03/09/2018).

Maskrey A, Mount NJ, Thorne CR and Dryden I (2016) Participatory modelling for stakeholder involvement in the development of flood risk management intervention options. Environmental Modelling \& Software 82: 275-294, https://doi.org/10.1016/j.envsoft.2016.04.027.
Mersha AN, Masih I, de Fraiture C, Wenninger J and Alamirew T (2018) Evaluating the impacts of IWRM policy actions on demand satisfaction and downstream water availability in the Upper Awash Basin, Ethiopia. Water 10(7): 892-912, https://doi.org/10.3390/w10070892.

Ministry of Water Development (1978) Rainfall Frequency Atlas of Kenya, Masterplanning Section. Ministry of Water Development, Nairobi, Kenya.

Mitra S, Mulligan J, Schilling J et al. (2017) Developing Risk or Resilience? Effects of Slum Upgrading on the Social Contract and Social Cohesion in Kibera, Nairobi. Environment and Urbanization Project, International Institute for Environment and Development, London, UK.

Mohamed N (2018) Sustainability Transitions in South Africa. Routledge, London, UK.

Morrison A, Noble BF and Westbrook CJ (2018) Flood risk management in the Canadian prairie provinces: defaulting towards flood resistance and recovery versus resilience. Canadian Water Resources Journal 43(1): 33-46, https://doi.org/10.1080/07011784.2018.1428501.

Mostert E (2003) The challenge of public participation. Water Policy 5(2): 179-197, https://doi.org/10.2166/wp.2003.0011.

Mowi (Ministry of Water and Irrigation) (2009) Flood Mitigation Strategy 2009. Ministry of Water and Irrigation, Nairobi, Kenya.

Mulligan J, Harper J, Kipkemboi P, Ngobi B and Collins A (2017) Community-responsive adaptation to flooding in Kibera, Kenya. Proceedings of the Institution of Civil Engineers - Engineering Sustainability 170(5): 268-280, https://doi.org/10.1680/jensu.15.00060.

Munene M (2018) Urban Resilience in Nairobi: Civil Society's Role and Interaction with Climate and Risk Science under Devolution. UrbanArk, London, UK, Working Paper No. 2. See https://www. urbanark.org/sites/default/files/resources/Martin-Urban\%20ARK\% 20Working\%20Paper\%202_0.pdf, (accessed 05/04/2019).

Mwiti SM (2014) Riparian Zone Conservation in a Changing Urban Land Use Environment: a Case of Nairobi River Basin, Kenya. Department of Urban and Regional Planning, University of Nairobi, Nairobi, Kenya. See http://erepository.uonbi.ac.ke/handle/11295/71646 (accessed 05/04/2019).

Ngobi B and Mulligan J (2017) The Institutional and Regulatory Context for Flood Risk Reduction in Kenya. KDI, Los Angeles, CA, USA. See https://www.kounkuey.org/report_170405_final_institutional_ mapping_report_kdi_screenview (accessed 03/09/2018).

O'Neill E (2018) Expanding the horizons of integrated flood risk management: a critical analysis from an Irish perspective. International Journal of River Basin Management 16(1): 71-77, https://doi.org/10.1080/15715124.2017.1351979.

Olang LO and Furst J (2011) Effects of land cover change on flood peak discharges and runoff volumes: model estimates for the Nyando River Basin, Kenya. Hydrological Processes 25(1): 80-89, https://doi.org/10. 1002/hyp.7821.

Olang LO, Kundu PM, Ouma G and Fürst J (2012) Impacts of land cover change scenarios on storm runoff generation: a basis for management of the Nyando Basin, Kenya. Land Degradation and Development 25(3): 267-277, https://doi.org/10.1002/ldr.2140.

Ondieki CM (2014) Hydrology and integrated water resource management for sustainable watershed management in Kenya. In Sustainable Practices: Concepts, Methodologies, Tools, and Applications (Khosrow-Pour M, Clarke S, Jennex ME et al. (eds)). IGI Global, Hershey, PA, USA, pp. 798-815.

Ouma GO, Dieye AM, Ogallo LO and Olang LO (2017) Institutional challenges in scaling-up climate change adaptation actions: experiences from rural communities in Senegal and Kenya. Climate and Development 10(7): 590-599, https://doi.org/10.1080/17565529.2017.1372261.

Parikh P, Parikh H and McRobie A (2012) The role of infrastructure in improving human settlements. Proceedings of the Institution of Civil Engineers - Urban Design and Planning 164(2): 61-73, https://doi. org/10.1680/udap.10.00038. 
Engineering Sustainability

Volume 172 Issue ES7
Participatory flood modelling for

negotiation and planning in urban

informal settlements

Mulligan, Bukachi, Gregoriou et al.
Ramani Huria (2018) Community Mapping for Flood Resilience and Development. Ramani Huria, Dar es Salaam, Tanzania. See http:// ramanihuria.org/ (accessed 03/09/2018).

Rees JA (1998) Regulation and private participation in the water and sanitation sector. Natural Resources Forum 22(2): 95-105, https://doi. org/10.1111/j.1477-8947.1998.tb00717.

ROK (Republic of Kenya) (2010) Constitution of Kenya 2010. National Council for Law Reporting, Nairobi, Kenya.

ROK (2016) The Water Act, 2016. National Council for Law Reporting, Nairobi, Kenya, Act No. 43 of 2016.

Sadoff CW and Grey D (2005) Cooperation on international rivers: a continuum for securing and sharing benefits. Water International 30(4): 420-427, https://doi.org/10.1080/02508060508691886.

Salami RO, von Meding JK and Giggins H (2017) Urban settlements' vulnerability to flood risks in African cities: a conceptual framework. Jàmbá: Journal of Disaster Risk Studies 9(1): 1-9, https://doi.org/10. 4102/jamba.v9i1.370.

Senaratna N, Baudoin MA, Oluoko-Odingo AA et al. (2014) Natural hazards and climate change in Kenya: Minimizing the impacts on vulnerable communities through early warning systems. In Reducing Disaster: Early Warning Systems for Climate Change (Singh A and Zommers Z (eds)). Springer, Dordrecht, the Netherlands, pp. 355-375.

Smith L, Liang Q, James P and Lin W (2017) Assessing the utility of social media for flood risk management. Journal of Flood Risk Management 10(3): 370-380, https://doi.org/10.1111/jfr3.12154.

Taylor J (2015) A tale of two cities: comparing alternative approaches to reducing the vulnerability of riverbank communities in two Indonesian cities. Environment and Urbanization 27(2): 621-636, https://doi.org/ $10.1177 / 0956247815594532$.

Tortajada C (2014) IWRM revisited: from concept to implementation. International Journal of Water Resources Development 30(3): 361-363, https://doi.org/10.1080/07900627.2014.937085.

van Oel PR, Odongo VO, Mulatu DW et al. (2014) Supporting IWRM through spatial integrated assessment in the Lake Naivasha basin, Kenya. International Journal of Water Resources Development 30(3): 605-618, https://doi.org/10.1080/07900627.2014.920248.

Venkateshwarlu S and Vijayabhole (2018) Flood level simulation modelling and vulnerability of slums along Musiriver, Hyderabad. International Journal of Humanities and Social Science Invention 7(5): 51-56.

Voinov A and Bousquet F (2010) Modelling with stakeholders. Environmental Modelling \& Software 25(11): 1268-1281.

Voinov A and Gaddis E (2008) Lessons for successful participatory watershed modelling: perspective from modelling practitioners. Ecological Modelling 216: 197-207, https://doi.org/10.1016/j. ecolmodel.2008.03.010.

Warner J (2007) The beauty of the beast: multi-stakeholder participation for integrated catchment management. In Multi-stakeholder Platforms for Integrated Water Management (Warner J (ed.)). Routledge, London, UK, pp. 1-20.

World Bank (2007) Western Kenya CDD and Flood Mitigation Project (English). World Bank, Washington, DC, USA. See http://documents. worldbank.org/curated/en/943961468047426131/Kenya-WesternKenya-CDD-and-Flood-Mitigation-Project (accessed 22/04/2019).

\section{How can you contribute?}

To discuss this paper, please email up to 500 words to the editor at journals@ice.org.uk. Your contribution will be forwarded to the author(s) for a reply and, if considered appropriate by the editorial board, it will be published as discussion in a future issue of the journal.

Proceedings journals rely entirely on contributions from the civil engineering profession (and allied disciplines). Information about how to submit your paper online is available at www.icevirtuallibrary.com/page/authors, where you will also find detailed author guidelines. 